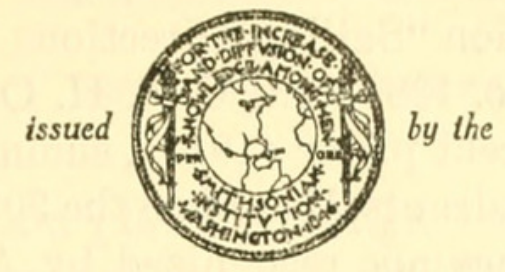

SMITHSONIAN INSTITUTION

U. S. NATIONAL MUSEUM

\title{
PYCNOGONIDA OF THE UNITED STATES NAVY ANTARCTIC EXPEDITION, 1947-48
}

\author{
By Joel W. Hedgpeth
}

Although the Antarctic waters are remote from the rest of the world, many elements of their fauna, including groups obscurely known elsewhere, are better known than are those of more accessible parts of the globe. This is especially true of the Pycnogonida, which have been the subject of several elaborate monographs, culminating in the recent comprehensive papers of Dr. Isabella Gordon, of the British Museum. Indeed, these curious little animals are perhaps better known in the Antarctic than anywhere else in the world, except in the waters adjacent to northern Europe. Certainly there is no other place from which a collection of 157 specimens, comprising 22 species in all, would reveal but one undescribed form.

The collections made by the United States Navy Antarctic Expedition of $1947-48$ are, for the most part, from regions already wellstudied. Of the 19 stations represented, 12 are from the vicinity of Peter I Island and Marguerite Bay on the western side of the Palmer Peninsula. The other stations are scattered from the Ross Sea to the Davis Sea along the coast of that vaguely defined area known as Wilkes Land. As Antarctic collections go, this collection is rather small, yet it provides a few extensions in range and an opportunity to clarify the status of a species of Nymphon previously known only from female specimens. In addition to this material from the Navy Antarctic Expedition, there is in the collections of the National Museum a small collection from South Georgia of uncertain provenance and some lots collected at Port Stanley, Falkland Islands. 
These collections are included in this paper in order to complete the listing of the Antarctic species possessed by the Museum.

The geographical names used in this paper are in agreement with that estimable publication "Sailing Directions for Antarctica" (U. S. Hydrographic Office No. 138), and U. S. H. O. Chart No. 2562. Dr. Gordon, in her most recent paper (1944), summarizes the distribution of many species by "quadrants," based on the $90^{\circ}$ sectors of the Antarctic, using a set of names not recognized by American geographers. The Gauss, Victoria, Ross, and Weddell quadrants, are, I presume, equivalent to the African, Australian, Pacific, and American quadrants of the National Geographic Society map. Yet she also mentions (p. 16) the "Enderby" quadrant, which is evidently the same as the Gauss quadrant. Perhaps it is unfair to mention this slight inconsistency in a work published during the war years, when it was impossible to send proofs to the author. However, the use of quadrants in summarizing Antarctic distribution is unsatisfactory, since the division is artificial. This is especially true of the Ross Sea area, a natural geographical region bisected by the 180th meridian and thus falling into two quadrants. It is probably best to use more general terms, such as Kerguelen and Magellan districts, and Ross and Weddell Sea areas, which in fact is Dr. Gordon's more usual practice.

\section{Family NYMPHONIDAE Wilson, 1878}

\section{Genus NYMPHON J. C. Fabricius, 1794}

Nymphon GoRDon, 1932b, pp. 26-36; 1944, pp. 17-22.

Gordon's fine comprehensive keys to the Antarctic species of this genus have greatly simplified the examination of Antarctic collections.

In addition to the species formally listed below, the following, all from South Georgia, are in the U. S. National Museum collections: Nymphon hiemale Hodgson, 2 females; Nymphon brevicaudatum Miers, 3 males, 4 females; Nymphon charcoti Bouvier, 3 females. These species have all been reported previously from this locality.

\section{NYMPHON AUSTRALE Hodgson}

Nymphon australe Hodgson, 1902, p. 257.

Chaetonymphon australe Hodgson, 1907, pp. 32-34, pl. 10, fig. 14.

Nymphon australe GoRdon, 1932b, pp. 59-63, figs. 25d, $26 \mathrm{~b}$.

\section{RECORD OF COLLECTIONS}

Station 43, 1 female; station 146, 1 female; station 150, 5 males, 2 females; station 164, 3 males.

One male and one female from South Georgia.

A circumpolar species. 


\section{NYMPHON ADAREANUM Hodgson}

Nymphon adareanum Hodgson, 1907, pp. 23-25, pl. 3, fig. 3.-CaLman, 1915b, pp. 33-34.-GoRdon, 1932a, pp. 98-101, figs. 1-2 (redescription; 1944, p. 20 (in key).

Station 190, 1 female.

RECORD OF COLLECTIONS

According to Gordon (1932a) there are usually 5-9 simple spines on the terminal segments of the oviger in the formula $2: 2: 2: 1$. This specimen, which otherwise agrees with the descriptions, has a formula of $2: 3: 2: 3$ with the suggestion of a fourth minute spine on the terminal segment. The previous records for this species are from Cape Adare (lat. $71^{\circ} 17^{\prime}$ S., long. $170^{\circ} 15^{\prime}$ E.), and this specimen, from Marguerite Bay on the western side of the Palmer Peninsula, is a considerable extension of the known range of this species.

\section{NYMPHON MULTIDENS Gordon}

FIgURE 17

Nymphon multidens Gordon, 1932b, pp. 75-76, figs. 34-35.-STEPHENSEN, 1947, p. 83.

RECORD OF COLLECTIONS

Station 150, 1 ovigerous male; station 164, 6 males ( 2 ov.), 6 females; station 226, 1 male, 1 female; case No. 1 , fragments.

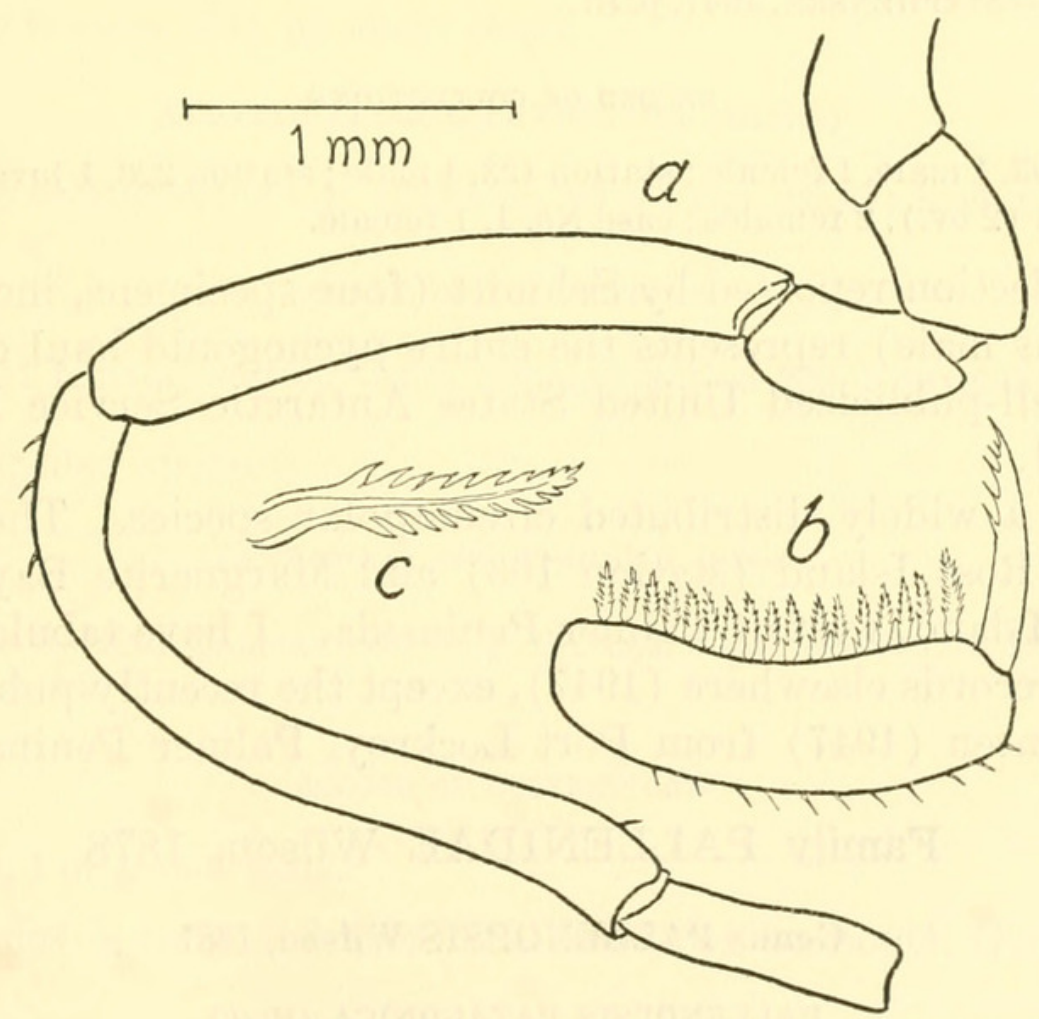

Figure 17.-Nymphon multidens Gordon: Oviger of male; $a$, joints $1-6 ; b$, terminal joint and claw; $c$, denticulate spine. 
This species was described from a single female specimen taken 1 mile off the east coast of Bouvet Island, and these records extend its range to the west coast of the Palmer Peninsula. As Dr. Gordon suspected, the male oviger belongs to her Group $I$ : the fourth joint is comparatively straight, and the fifth is curved in its proximal third and is without any swellings or processes. The spine formula of the terminal segments of the oviger is $23: 18-20 ; 17: 17:: 6$. The denticulation of the terminal spine of the oviger is restricted to the distal half. The chelae of several of the male specimens have black-tipped fingers.

Stephensen's records indicate the occurrence of this species near Peter I Island; both of his specimèns are evidently females.

\section{NYMPHON sp.}

RECORD OF COLLECTIONS

Station 238, 2 juveniles.

These specimens are too young for determination, but they appear to be intermediate between subtile and paucidens, suggesting the close relationship of these two species.

\section{PENTANYMPHON ANTARCTICUM Hodgson}

Pentanymphon antarcticum Hodgson, 1904, pp. 458-462, 1 pl.; 1907, pp. 36-39, pl. 5.-Gordon, 1932b, pp. 24-26; 1944, p. 14.-Schмiтt, 1945, p. 297.Hedgreth, 1947, p. 13 ff., fig. 6, pp. 51-53 (dist. table), figs. 4, 11 (dist. maps ).-STEPHENSEN, 1947, p. 81.

\section{RECORD OF COLLECTIONS}

Station 103, 1 male, 1 female; station 193,1 male; station 226,1 juvenile; station 237, 4 males ( 2 ov. ), 2 females; case No. 1, 1 female.

The collection reported by Schmitt (four specimens, including one larvigerous male) represents the entire pycnogonid haul of Admiral Byrd's well-publicized United States Antarctic Service Expedition of $1939-41$.

This is a widely distributed circumpolar species. These records are from Ross Island (station 103) and Marguerite Bay, south of Adelaide Island, west of Palmer Peninsula. I have tabulated all the previous records elsewhere (1947), except the recently published ones of Stephensen (1947) from Port Lockroy, Palmer Peninsula.

\section{Family PALLENIDAE Wilson, 1878}

\section{Genus PALLENOPSIS Wilson, 1881}

\section{PALLENOPSIS PATAGONICA (Hoek)}

Phoxichilidium patagonicum HoEk, 1881, pp. 84-86, pl. 12, figs. 6-9.

Pallenopsis patagonica Gondon, 1932b, pp. 88-90, fig. 44; 1944, pp. 46-48, fig. 15, $\mathrm{b}, \mathrm{d}, \mathrm{e}$. 
RECORD OF COLLECTIONS

Station 31, 1 female.

South Georgia (U. S. N. M.), 1 specimen.

Not a rare species; often found in the Magellan district.

\section{PALLENOPSIS VANHÖFFENI Hodgson}

Pallenopsis vanhöffeni Hodgson, 1915, p. 145.-Gokdon, 1938, pp. 17-18, flgs. 3b, 4a, 5c, 6c-d (redescription).

$$
\text { RECORD OF COLLECTIONS }
$$

Station 12, 1 female.

Occurs sparingly off the coast of Wilkes Land.

\section{PALLENOPSIS HODGSONI Gordon}

Pallenopsis hodgsoni Gordon, 1938, pp. 16-17, figs. 3a, 4d, 5d (pro P. pilosa auct.) .

RECORD OF COLLECTIONS

Station 43, 1 female (with foraminifers and bryozoans).

A widely distributed Antarctic species, in water less than 350 fathoms.

\section{Genus AUSTROPALLENE Hodgson, 1907}

Austropallene GoRdon, 1944, pp. 36-37 (key).

\section{AUSTROPALLENE CORNIGERA (Möbius)}

Austropallene cornigera GoRDon, 1932b, pp. 85-86, figs. 42-43; 1944, p. 37.

RECORD OF COLLECTIONS

Station 43, 1 female; station 104, 1 female; station 226, 1 juvenile.

A circumpolar species.

\section{AUSTropallene tibicina Caiman}

Austropallene tibicina Calman, 1915b, p. 39, figs. 7-8.-Gordon, 1944, pp. 41-42, figs. $12 \mathrm{~b}-\mathrm{d}, 14 \mathrm{e}$.

\section{RECORD OF COLLECTIONS}

Station 104, 1 ovigerous male.

This species is recorded from the Ross Sea to South Georgia. 


\section{Family AMMOTHEIDAE Dohm, 1881}

Genus AMMOTHEA Leach, 1815

\section{AMMOTHEA CAROLINENSIS Leach}

Ammothea carolinensis LeACH, 1814, p. 34, pl. 13.-CALMAN, 1915a, pp. 310-315, figs. 1-3.-Gordon, 1932b, p. 109.

RECORD OF COLLECTIONS

Station 237, 1 male, 1 female.

This large species occurs in the western Antarctic, from South Georgia southward.

\section{AMMOThea CLAUSi Pfeffer}

Ammothea clausi Pfeffer, 1889, p. 45.-Bouvier, 1913, p. 135, figs. 88-89.-Gordon, 1932b, pp. 109-110.

\section{RECORD OF COLLECTIONS}

Station 146, 1 juvenile; station 148, 1 male; station 150, 9 males (3 ov.), 13 females, 11 juveniles; station 151, 1 juvenile; station 164, 11 males ( 2 ov.), 21 females, 3 juveniles ( 2 or 3 specimens with encrusting Bryozoa and small serpulids) ; station 226, 1 juvenile; station 237, 1 male, 1 female; case No. 1, 1 male, 1 juvenile.

South Georgia (U.S.N.M.), 1 specimen.

This is apparently a common species in the South Georgia-Bellingshausen Sea area.

\section{AMMOTHEA GIBBOSA (Möbius)}

Colossendeis gibbosa MöвIUs, 1902, p. 192, pl. 30, figs. 1-5.

Ammothea gibbosa Calman, 1915b, p. 51.-Gordon, 1938, pp. 20-21.

$$
\text { RECORD OF COLLECTIONS }
$$

Station 150, 1 female, 2 juveniles.

\section{AMMOTHEA GLACIALIS (Hodgson)}

Leionymphon glaciale Hodgson, 1907, p. 50, pl. 7, fig. 3. Ammothea glacialis GoRDon, 1944, pp. 51-52.

\section{RECORD OF COLLECTIONS}

Station 104, 1 male (with several small serpulids), 2 juveniles.

This species is found along the coast of Wilkes Land and in the Ross Sea. 


\section{ACHELIA COMMUNIS (Bouvier)}

Ammothea communis Bouvier, 1906, pp. 20, 44-50, figs. 23-32.

Ammothea affinis Bouvier, 1906, p. 50.

Achelia communis Bouvier, 1913, pp. 144-145.-CaLman, 1915b, p. 57 (key).GoRDon, 1932b, figs. 59c, 60b; 1944, p. 53.

\section{RECORD OF COLLECTIONS}

Station 164, 1 female; station 238, 1 female; case No. 1,1 ov. male, 2 juveniles.

Found from the South Orkneys and South Shetlands; Gordon (1944) records it from off Enderby Land.

\section{ACHELIA SPICATA (Hodgson)}

Austrothea spicata Hodgson, 1915, p. 147.

Achelia spicata Calman, 1915b, pp. 57-60, figs. 13-14.-Gordon, 1938, p. 23; 1944, p. 52 .

RECORD OF COLLECTIONS

Station 104, 2 males, 1 female, 1 juvenile.

The auxiliary claws of one of the male specimens are longer than is usual for this species, but all other characters agree.

\section{ACHELIA INTERMEDIA Calman}

Achelia intermedia Calman, 1915b, p. 60, fig. 15.-GoRdon, 1932b, fig. 59c, 60b ; 1944, p. 52.-STEPHENSEN, 1947, p. 85.

RECORD OF COLLECTIONS

Station 33, 1 juvenile.

Gordon (1944) considers this "probably" a circumpolar species.

\section{ACHELIA PARVULA Loman}

Achelia parvula Loman, 1923, p. 2, fig. A.-Gondon, 1932b, pp. 113-114, fig. 62.

\section{RECORD OF COLLECTIONS}

Port Stanley, Falkland Islands, 5 lots, 32 specimens, collected by W. L. Schmitt, as follows :

No. 81. Boat dredge, above battle monument; February 23, 1927 ; 1 sp.

No. 92, South of municipal jetty, March 16, 1927; 6 specimens (4 of these, later culled from tunicates, are in the A. M. N. H. collections).

No. 93. Boat dredge, off coal dock, March 17, 1927; 1 specimen.

No. 97. 8-10 fathoms, March 20,$1927 ; 6$ specimens.

No. 107. Taken with clam rake from under side of the Great Britain, April 14,1927 , from 1 fathom to surface; 18 specimens.

This is evidently a common species in the Falklands. It also occurs in the Straits of Magellan. 
ACHELIA sp.

RECORD OF COLLECTIONS

Station 234, 2 juveniles.

These specimens are too immature for determination, although they may be Achelia brucei Calman.

\section{Genus AUSTRORAPTUS Hodgson, 1907}

\section{AUSTRORAPTUS POLARIS Hodgson}

Austroraptus polaris Hodgson, 1907, p. 54, pl. 8, figs. 2.-GoRdon, 1932b, p. 114.

There is one male specimen from South Georgia in the U.S.N.M. collections.

\section{Genus AUSTRODECUS Hodgson, 1907}

\section{AUSTRODECUS GLACIALE Hodgson}

Austrodecus glaciale Hodgson, 1907, pp. 53-54, pl. 8, fig. 1.-Gokdon, 1944, pp. 62-66, figs. 24a-f, 25a-e.

RECORD OF COLLECTIONS

Station 43, 1 female; station 234, 1 male, 1 female; station 238, 1 male; case No. 1,1 male, 1 female.

Port Stanley, Falkland Islands, collected by W. L. Schmitt :

No. 92. South of municipal jetty, March 16,$1927 ; 1$ specimen (A. M. N. H.)

No. 97. 8-10 fathoms; March 20, 1927 ; 2 specimens.

No. 105. Port William, oyster dredge off lighthouse, 14-15 fathoms ; April 9, 1927 ; 1 specimen.

No. 107. Clam rake, from under side of the Great Britain, April 14, 1927, from 1 fathom to surface; 1 specimen.

The specimen from Station 43 (lat. $65^{\circ} 25^{\prime}$ S., long. $101^{\circ} 13^{\prime}$ E.) agrees with Gordon's variety $\beta$ described from this general region in its generally more extended proportions and longer eye tubercle. Evidently this is a true geographical race if not a distinct variety.

\section{AUSTRODECUS BREVICEPS Gordor}

Austrodecus breviceps Gondon, 1938, pp. 25-26, figs. 7-8.

RECORD OF COLLECTIONS

Station 192, 1 male.

This is the second record for this species, extending the known range from Macquarie Island to the western side of the Palmer Peninsula. 


\title{
Genus RHYNCHOTHORAX Dohrn, 1881
}

\section{RHYNCHOTHORAX AUSTRALIS Hodgson}

Rhynchothorax australis Hodgson, 1907, pp. 57-58, pl. 8, fig. 3.-CALMAN, 1915b, pp. 67-68, fig. 21.-GoRdon, 1932b, p. $122 ; 1944$, pp. 67-68.

\author{
RECORD OF COLLECTIONS
}

Station 47, 1 male.

This species ranges from off Wilkes Land to Ross Sea and the Antarctic Archipelago.

\section{Genus BOEHMIA Hoek, 1881}

(?) BOEHMIA DUBIA, new species

Figure 18

RECORD OF COLLECTIONS

Holotype (U. S. N. M. No. 87608) : 1 female (?), station 104, off Cape Royds, Ross Island, 58 fathoms, January 29, 1948.

Paratype (U.S. N. M. No. 87609) : 1 juvenile.

This little beast is an ambiguous anomaly, and on the basis of these specimens alone it cannot be safely referred to an established genus. It is possible that the type specimen is a penultimate molt stage and that ovigers will appear in the adult. If future collections demonstrate that the absence of ovigers is a constant character in the females of this species, it must be removed from the Ammotheidae altogether, or considered an aberrant member of the family. It would then have close affinities with the Phoxichilidiidae, although the possession of well-developed ammotheid palpi would impair the definition of that family. It seems hardly justifiable even to erect a new genus for this form, although its well-developed auxiliary claws separate it from the species referred to Boehmia. The chelifores and palpi, however, as well as the general aspect of the creature, suggest that genus.

Description.-Trunk oval in outline, lateral processes distinctly separated, trunk segments marked off by well-developed annular divisions. Cephalic segment projected forward, with several sharp conical processes at the outer anterior corners over the insertion of the chelifores. There are also conical or thornlike processes on the corners of the lateral processes and the first coxae. The eye tubercle is a tall, pointed, narrow cone, with well-developed eyes about halfway between the base and apex. The first three trunk segments each bear a slender conical process about as tall as the eye tubercle near the posterior margins of the segments, which are actually prolongations of the dorsal portion of the annular swellings which mark off the segments. Pro- 
boscis curved downward, tapering to a blunt, rounded point, cylindrical at the base. The chelifores and palpi arise from a rim around the base of the proboscis.

Chelifore: 2-jointed, the scape armed with a thick-set group of thornlike processes on the dorsal distal half. Chela slightly larger than scape, fingers bowed, without teeth, tips overlapping. There is a sharp process on the outer margin of the palm over the insertion of the dactylus.

Palpus: 7-jointed, first and third short, subequal, second and fourth long, second about three-fourths as long as the fourth. Three terminal joints short, fifth and seventh subequal, sixth slightly longer. The palpus originates directly below the chelifore.

Ovigers: Absent.

Third leg rather stout, first and third coxae subequal, second slightly longer. There are several spurs on the first, and one or two on the second coxa. Femur plain, slightly curved, subequal to first tibia. Second tibia longer than first. Tibiae armed dorsally with sharp spurlike processes; and bearing short spines along the ventral surfaces. Tarsus short, cuplike, with a large spine dorsally and a larger one ventrally accompanied by several small spines. Propodus slightly arched, sole armed with one very large spine proximally and two
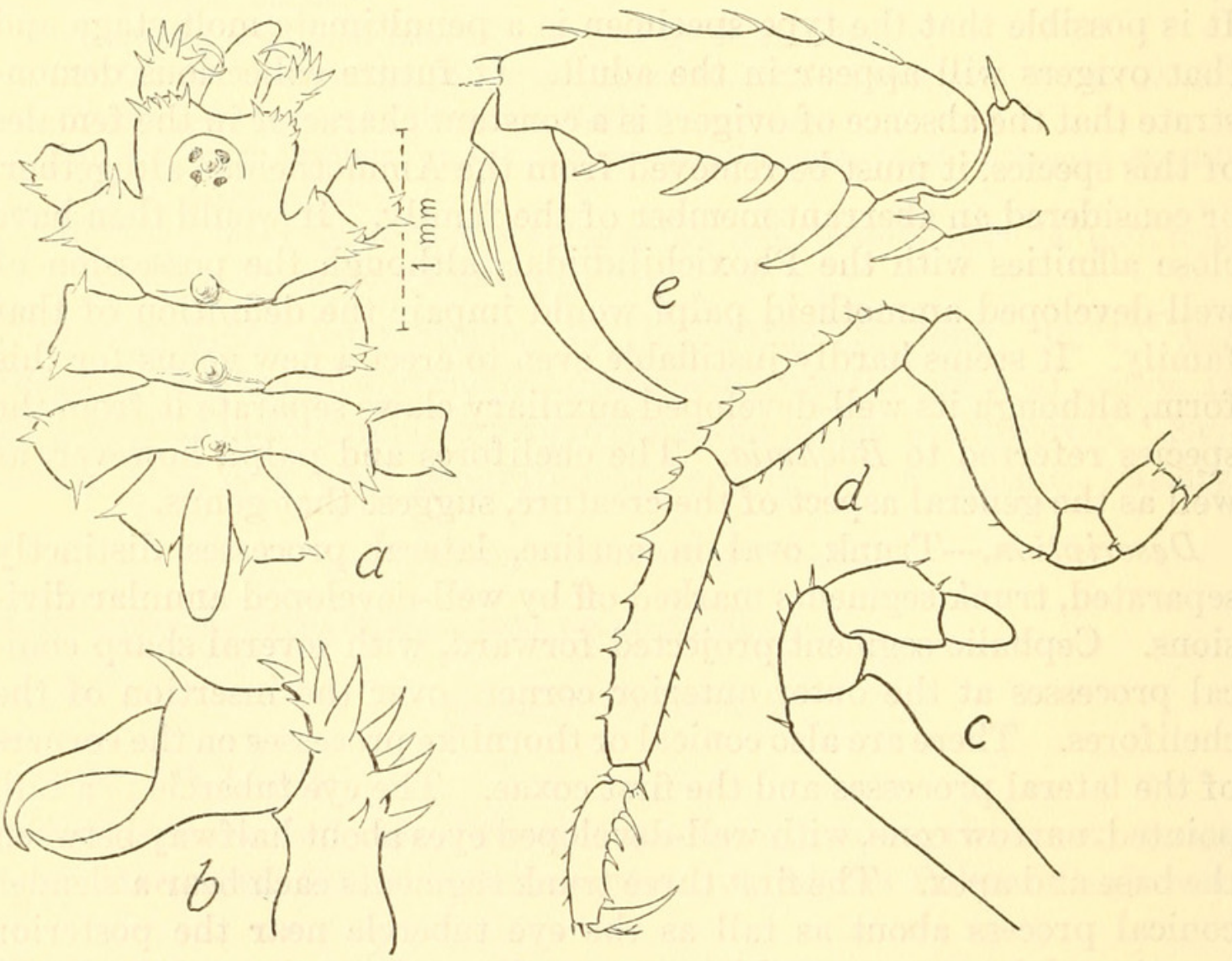

FigURE 18.-? Boehmia dubia, new species: $a$, Dorsal view of trunk; $b$, chela; $c$, joints 4-7 of palpus; $d$, leg; $e$, tarsus and propodus. 
smaller ones near the middle, and a much smaller one near the base of the claw. Claw almost as long as propodus, curved. Auxiliary claws about a third as long as the terminal claw.

\section{Measurements of holotype.-As follows:}

Mm. Third leg:

Mm.

Trunk

Coxae

0.09

Abdomen

Femur

1. 25

Proboscis

First tibia

1.25

Width, second lateral process

ca. 1.0

Second tibia

1.5

Chelifore :

Scape

Tarsus

.1

Chela

Propodus

.7

Terminal claw------------- .5

Remarks.-As already noted above, this is an ambiguous curiosity. The holotype specimen appears to be a female. I could find no genital pores, and the specimen is evidently immature. The other specimen is about three-fourths as large, with only the first three pairs of legs fully developed, the fourth pair being represented by single jointed buds. Like the larger specimen it has no trace of ovigers. The welldeveloped palpi and propodus of both individuals suggest that the holotype specimen is a relatively late stage. 


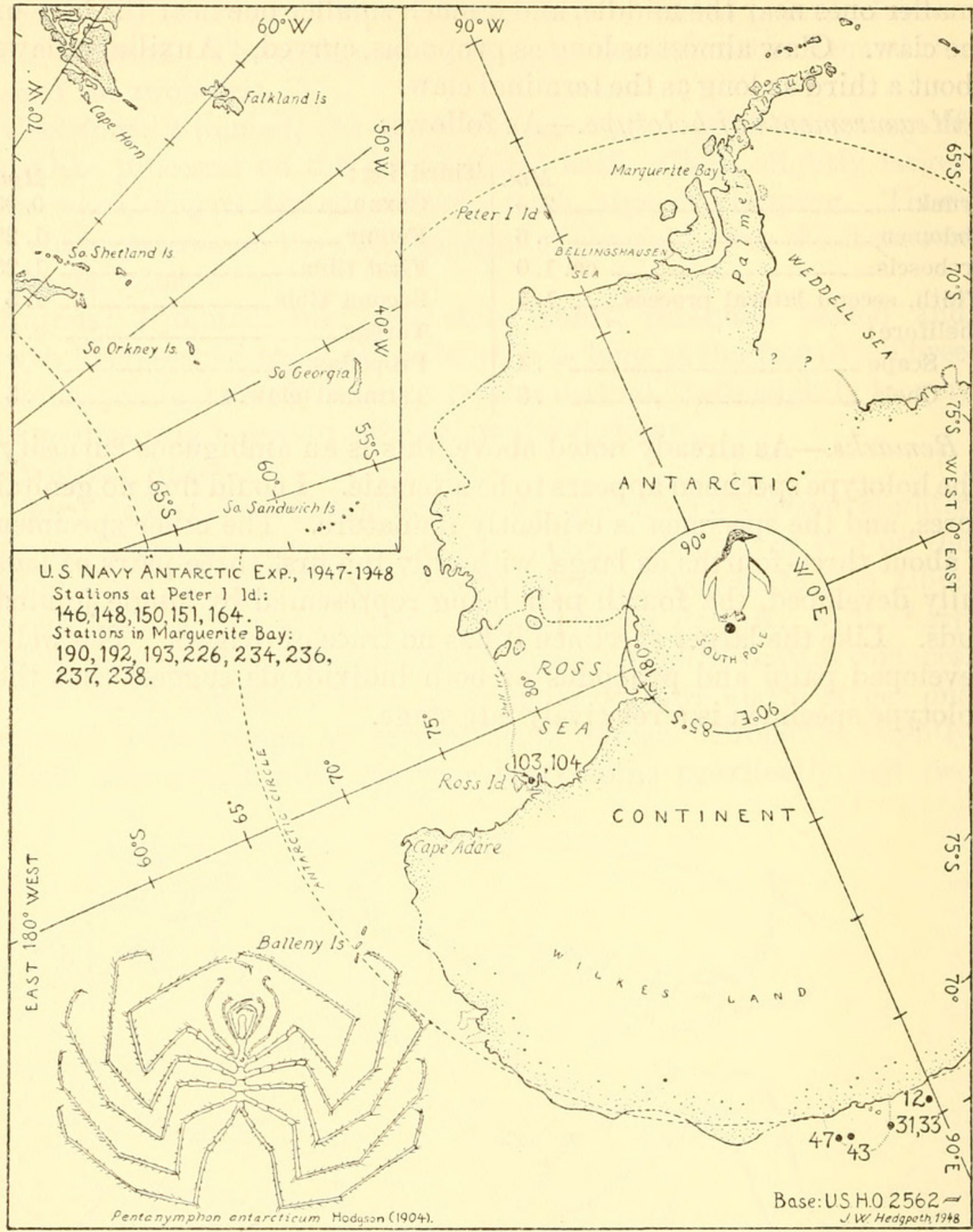

Figure 19.-Chart showing stations of the United States Navy Antarctic Expedition, $1947-48$, and localities mentioned in this report. 
TABLE 1.-List of stations of the United States Navy Antarctic Expedition, $1947-48$

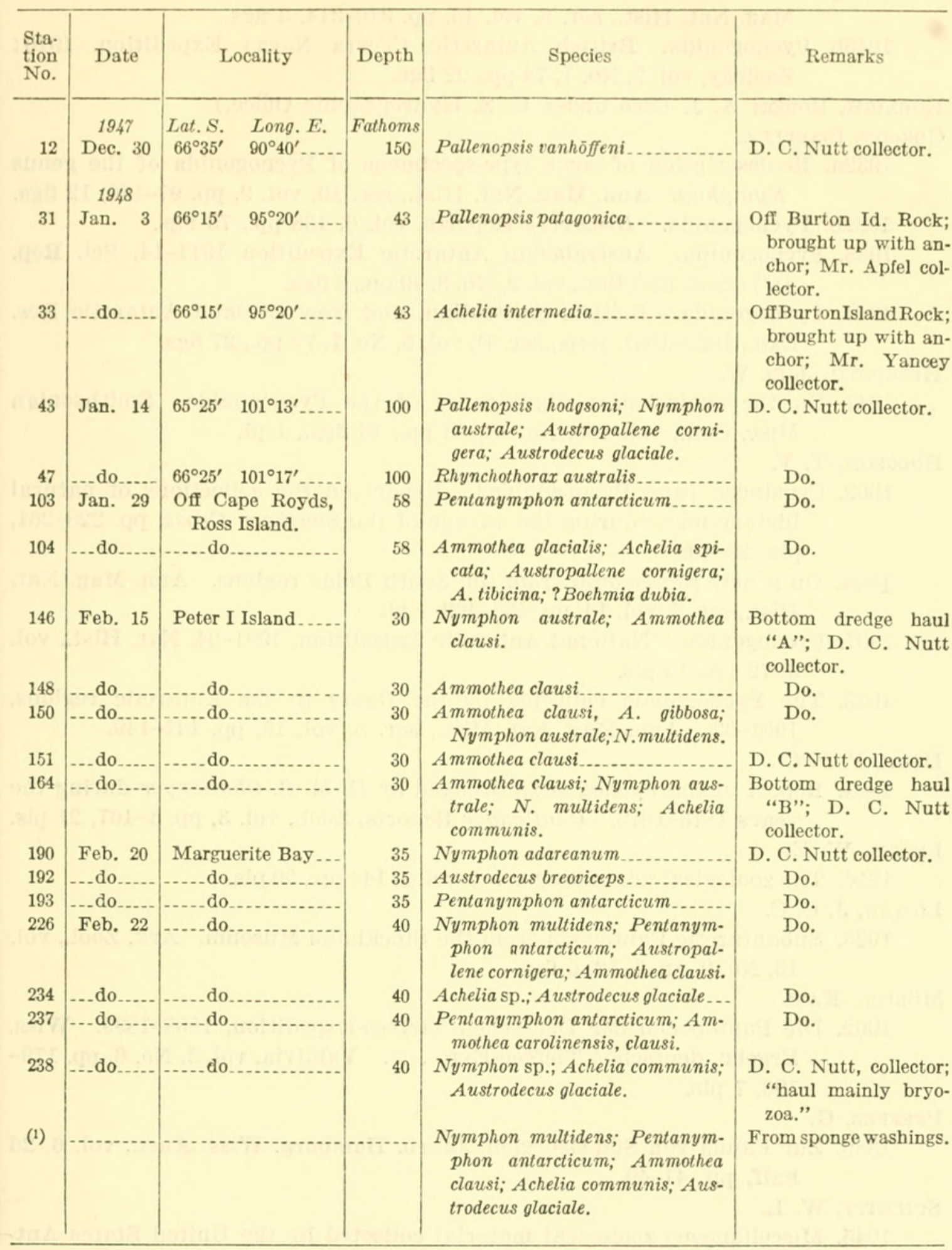

${ }^{1}$ Case No. 1 (no label).

\section{LITERATURE CITED}

Bouvier, E. L.

1906. Pycnogonides du Français. Expédition Antarctique Français (190305), 60 pp., 48 figs., 3 pls.

1913. Pycnogonides du Porquoi Pas? Deuxième Expédition Antarctique Francaise (1908-1910), vol. 6, 169 pp., 109 figs. 
Calman, W. T.

1915a. The holotype of Ammothea carolinensis Leach (Pycnogonida). Ann.

Mag. Nat. Hist., ser. 8, vol. 15, pp. 310-314, 3 figs.

1915b. Pycnogonida. British Antarctic (Terra Nova) Expedition, 1910; Zoology, vol. 3, No. 1, 74 pp., 22 figs.

ENgLish, Robert A. J. (See under U. S. Hydrographic Office.)

GoRdon, IsABELla.

1932a. Re-description of some type-specimens of Pycnogonida of the genus

Nymphon. Ann. Mag. Nat. Hist., ser. 10, vol. 9, pp. 97-120, 12 figs.

1932b. Pycnogonida. Discovery Reports, vol. 6, 138 pp., 75 figs.

1938. Pycnogonida. Australasian Antarctic Expedition 1911-14, Sci. Rep.

(C), Zool. and Bot., vol. 2, No. 8, 40 pp., 8 figs.

1944. Pycnogonida. British, Australian, and New Zealand Antarctic Res.

Exp., 1929-1931, Rep., ser. B, vol. 5, No. 1, 72 pp., 27 figs.

Hedgpeth, Joel W.

1947. On the evolutionary significance of the Pycnogonida. Smithsonian Misc. Coll., vol. 106, No. 18, 53 pp., 16 figs., 1 pl.

Hodgson, T. V.

1902. Crustacea [and Pycnogonida]. Report on the collections of natural

history made during the voyage of the Southern Cross, pp. 228-261, pls. $29-40$.

1904. On a new pycnogonid from the South Polar regions. Ann. Mag. Nat. Hist., ser. 7, vol. 14, pp. 458-462, 1 pl.

1907. Pycnogonida. National Antarctic Expedition, 1901-04, Nat. Hist., vol. 3,72 pp., 10 pls.

1915. The Pycnogonida collected by the Gauss in the Antarctic regions, 1901-03. Ann. Mag. Nat. Hist., ser. 8, vol. 15, pp. 141-149.

HоEк, P. P. C.

1881. Report of the Pycnogonida dredged by H. M. S. Challenger during the years 1873-1876. Challenger Reports, Zool., vol. 3, pp. 1-167, 21 pls.

LEACH, W. E.

1814. The zoological miscellany . . ., vol. 1, 144 pp., 60 pls.

Loman, J. C. C.

1923. Subantarctic Pantopoda from the Stockholm Museum. Ark. Zool., vol. 15, No. 9, pp. 1-13, 5 figs.

MÖBIUS, KARL

1902. Die Pantopoden der Deutschen Tiefsee-Expedition, 1898-1899. Wiss. Ergebn. deutschen Tiefsee-Exp. . . . Valdivia, vol. 3, No. 6, pp. 179196, 7 pls.

Pfeffer, G.

1889. Zur Fauna von Süd-Georgien. Jahrb. Hamburg. Wiss. Anst., vol. 6, 2d half, pp. 41-49.

SсH мIтт, W. L.

1945. Miscellaneous zoological material collected by the United States Antarctic Service Expedition, 1939-1941. Proc. Amer. Philos. Soc., vol. 89, No. 1, p. 297.

StePhensen, K.

1947. Tanaidacea, Isopoda, Amphipoda and Pycnogonida. Sci. Res. Norweg. Antaretic Exp. 1927-28, No. 27, 90 pp., 24 figs. [Pycnogonida, pp. 80-86.]

United States Hydrographic Office.

1943. Sailing directions for Antarctica; including the off-lying islands south of latitude $60^{\circ}$. H. O. No. 138, 312 pp. illus., chart. 


\section{$2 \mathrm{BHL}$ Biodiversity Heritage Library}

Hedgpeth, Joel W. 1950. "Pycnogonida of the United States Navy Antarctic Expedition, 1947-48." Proceedings of the United States National Museum 100, 147-160.

View This Item Online: https://www.biodiversitylibrary.org/item/53452

Permalink: https://www.biodiversitylibrary.org/partpdf/52105

\section{Holding Institution}

Smithsonian Libraries

\section{Sponsored by}

Smithsonian

\section{Copyright \& Reuse}

Copyright Status: Public domain. The BHL considers that this work is no longer under copyright protection.

This document was created from content at the Biodiversity Heritage Library, the world's largest open access digital library for biodiversity literature and archives. Visit BHL at https://www.biodiversitylibrary.org. 